\title{
REMAINS OF ARCHAIC TEMPLE OF ARTEMIS AT EPHESUS.
}

\author{
[Plates III., IV.]
}

WHEN Mr. Wood in his patient and successful excavation of the temple of Artemis at Ephesus had got down to the natural soil, he observel a number of massive piers underneath the walls of the cella, or rather where the cella walls onght to have been. On the plan in his book he indicates these piers by dotted lines, supposing them to have been made to support the walls of a church built in late times after the temple had been destroyed. It may have been so. But there appears to be no other indication of such a church on the site. This much is certain, that in building these piers a free use had been made of the fragments lying at hand from the older temple which had been destroyed by fire on the night, as we are so often told, when Alexander was born. Fragments of the old frieze and cornice would build in like so many bricks, and give the piers that solidity which Mr. Wood could only break into, as he did reluctantly, by blasting. The result of the blasting was that he obtained a number of archaic fragments of sculpture and architecture which we have now to consider. That happened in 1874. Previously in 1872, he had found some fragments of the same archaic character, not built into piers but apparently loosely mixed with sculpture of a later age.

These arclaic fragments when they reached the Museum were the subject of much consideration. Sir Charles Newton dealt with them in a paper in the Portfoiio (June, 1874), suggesting that they might be the remains of a small $\theta \rho$ crкós which Pausanias (x. 38, 3) says ran along the top of the altar of Artemis Protothronia at Ephesus, above which there stood among other figures a statue of Night, by the early artist Rhoecos. ${ }^{1}$ It must have been this association of the marble $\theta \rho$ crós with an artist like Rhoecos that led Sir Charles Newton to this suggestion. Rhoecos is too early for sculpture of this kind. Besides it is proposed to show that these

1 See also Wond's Elhesals, 1. 201.

H.S.-VOI. X. 


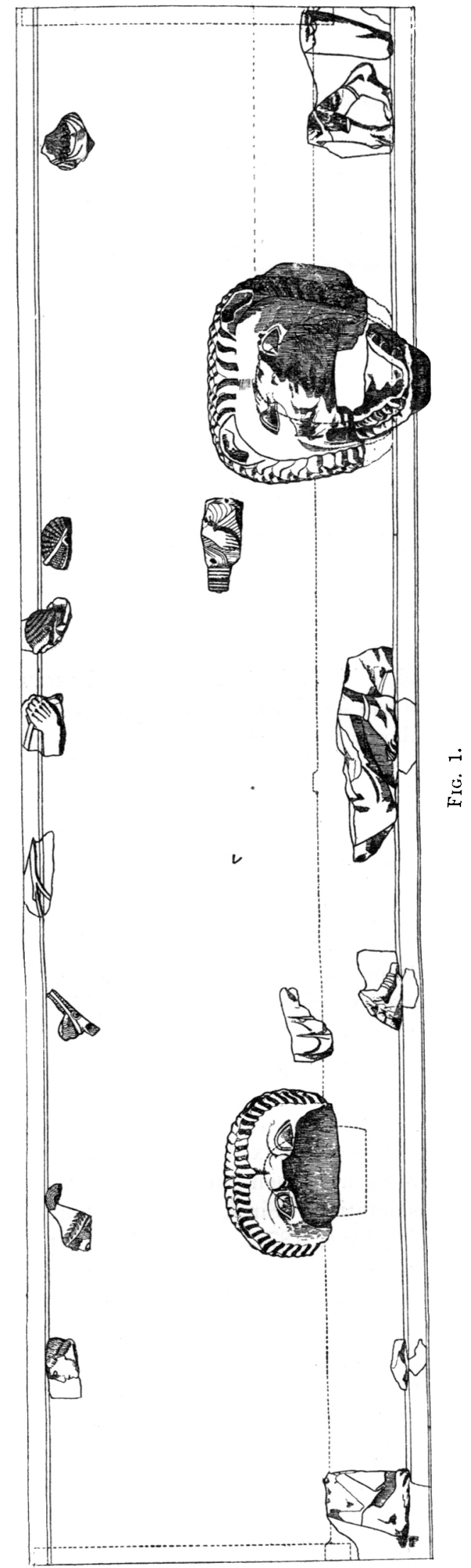


REMAINS OF ARCHAIC TEMPLE OF ARTEMIS AT EPHESUS. 3

fragments belonged to the cornice of the temple itself. One of the results of my endeavours to put these fragments together is exbibited in a drawing here (Fig. 1). The actual re-construction may be seen in the Archaic room of the Museum. I do not claim that every fragment is in absolutely its right place. But it seemed a matter of so much importance to show what the cornice of the old temple was like, that I have ventured to place the fragments here in

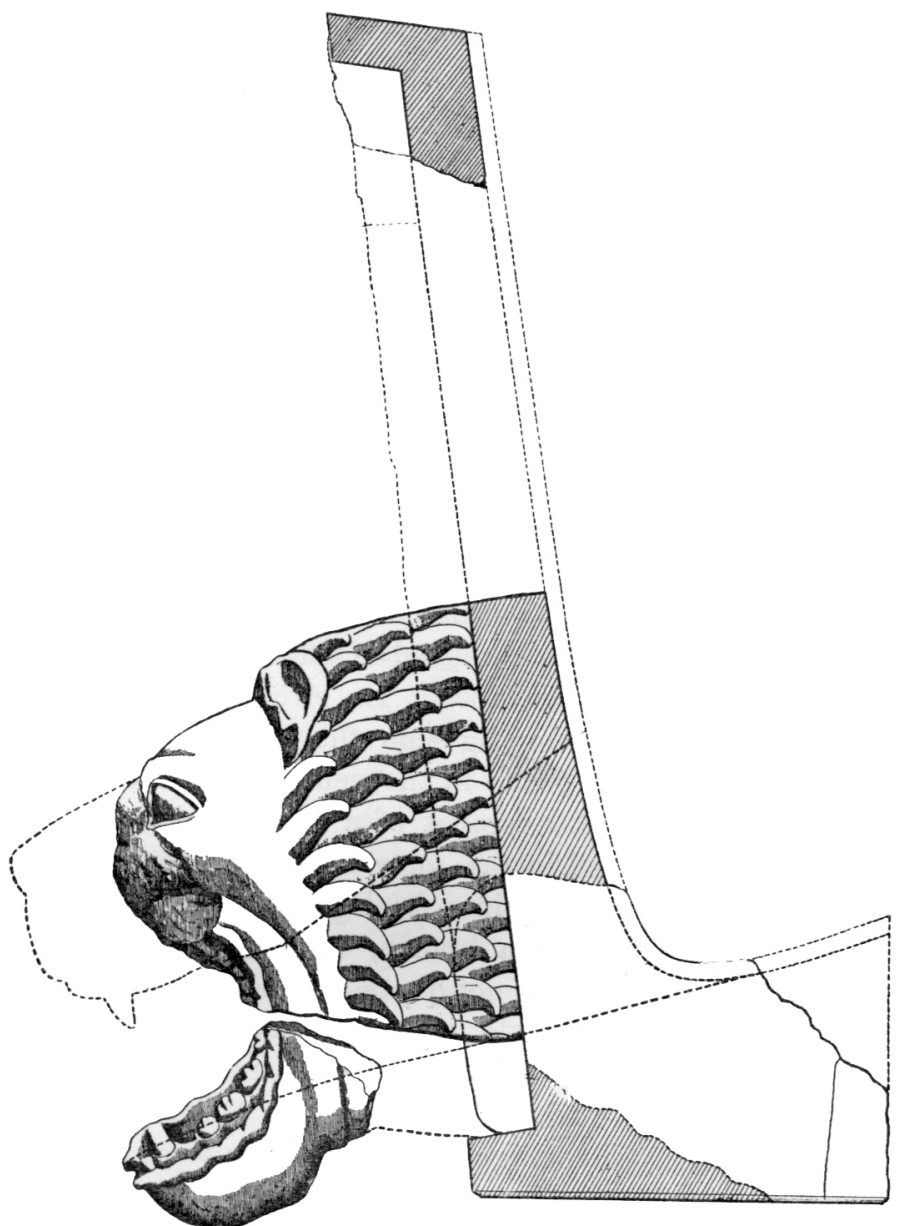

Fig 2.

their relatively true places. It would have been pedantry not to do so much, since each fragment is in its place relatively at least, and possibly in its true place absolutely.

We have thus a cornice in which the spaces between the lions' heads where the rain on the roof escaped, are occupied not by floral ornaments as in the later temple, and in Greek architecture in general, but by groups 
sculptured with extraordinary minuteness and delicacy, so much so that Mr. Woor could not at first sight believe the re-construction possible. A few moments of observation convinced him that the thing was right. He was good enough to send me his mensurements for the distance between the lions' heads, and they agreed very closely with what $I$ had arrived at. The height of the cornice was taken from a comparison with the reliefs of the Harpy tomb in the Museum, which belong to about the same period of art.

It may be mentioned that though we possess a considerable number of fragments from what I have claimed as the cornice of the temple, yet hardly any two of them have been found to fit together, notwithstanding long and continuous efforts. From this it may be argued that these many isolated fragments had belonged to a very extensive piece of sculpture, such as the cornice of a great temple, they being a mere fraction of the whole. In restoring a part of the cornice from them, I was led originally by the observation that the working of the back and joints of the stones is precisely of the same kind as that of the cornice of the later temple, regular divisions being made in the gutter so that the water collecting from the roof might flow out at the lions' mouths at regular intervals (Fig. 2). No doubt the cornice as here restored wants the graceful profile of later architecture, but that, I understand, is not altogether without precedent. A selection from the remaining fragments will be found on Plate $1 V$.

As regards the designs represented in these sculptures, we may suppose either that they had formed a continuous subject, separated into groups by the lions' heads, or that they had consisted of an extensive series of separate subjects, in the manner of metopes. In either case this separation of sculptured groups may throw some light on the origin of metopes. I have only attempted to suggest one group in the centre of the diagram, a group which may be restored as the combat of a Greek and a Centaur following the analogy of a gem engraved in the Journal of Hellenic Studies (I. p. 130). The Centaur has human not equine forelegs - a circumstance familiar in archaic art. The hand holding a branch, which is let in at the top, is so suitable for a Centaur, that I need not quote instances of it.

In the matter of artistic style, reference has already been made to the Harpy tomb. The Ephesian cornice is on a rather smaller scale, and the figures more minutely finished. Except for that the comparison ought to stand good. The date usually assigned to the Harpy tomb is about 550 B.c. There is no reason why our cornice should not be about the same period.

Among the other fragments of the archaic temple were some which have been known for a while as remains of sculptured columns (see Plate III). It was known in a general way that the sculptured columns-columnae coelatae - which adorned the temple of Alexander's time, as we learn from Pliny, and from the sculptured drums found by Mr. Wood, had in fact been copied from the older temple, not necessarily as regards the subjects, still less as regards the style, but in the general idea. No one however took up the idea to work it out or disprove it. We have now put together part of one of these archaic columns. As regards the figure on the lowest drum, I do not of 
course vouch that the upper part belongs absolutely to the lower. It is a matter of general truth only. There must have been some such upper part to the figure. The whole answers fairly to the Hermes on an archaic vase from Corinth, in the British Museum. It will be observed that under the feet of the figure is a flat band, which does not exist in the later temple. Next comes a torus moulding, as in the later temple, but smaller. In the

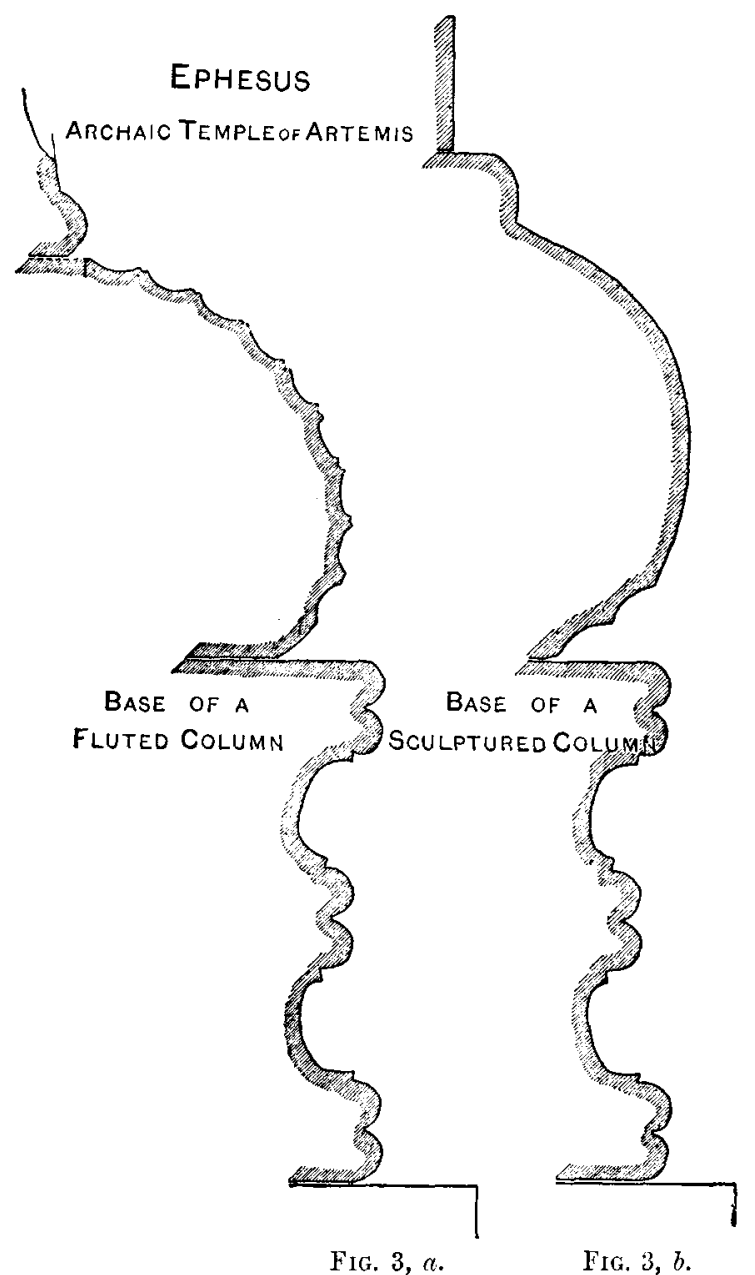

restoration of this moulding I have employed the fragments which, according to Mr. Hicks' quite obvious conjecture, are inscribed with the name and dedication of Croesos. 1 We were guided to that by a large piece of unfinished base moulding in the Museum, on the upper edge of which is carved a torus exactly the same as that of the inscribed fragments (Fig. 3,b). Finding 


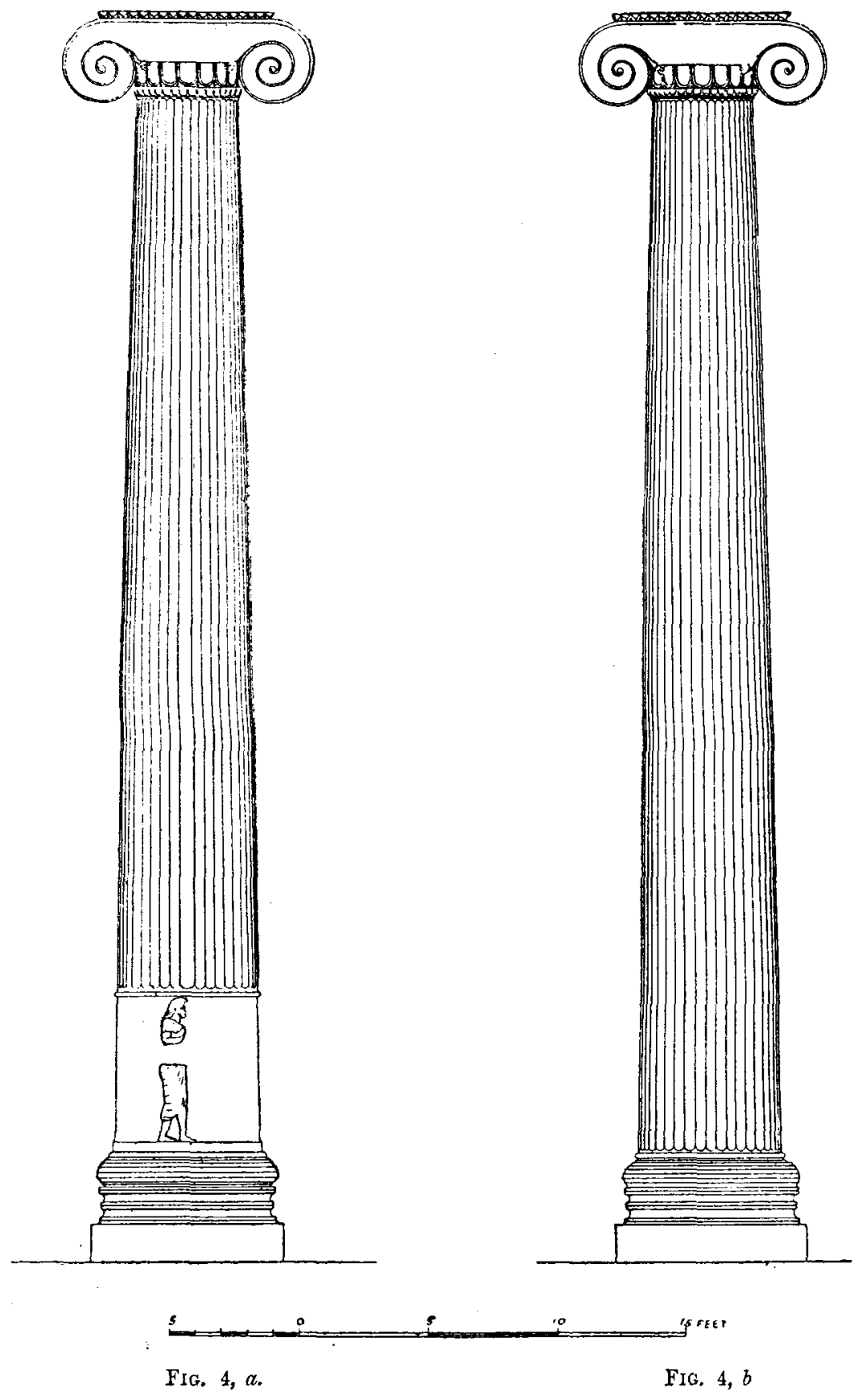


several pieces of this upper member finished with horizontal flutings but incomplete at the top, I have placed the inscribed fragments above them. Those who recollect the base of the later temple, in the Museum, will know that it has in this place a fluted member of this same character. The profile, however, is quite different, as would be expected in architecture of such widely different dates.

Finding that up to this point the new temple had in general copied the old, I decided, after an unsatisfactory experiment, to try whether the remaining base of the new temple might give a clue for restoring the lowest part of the archaic base. Among the archaic fragments we found a number of pieces which answered perfectly to this idea (Figs. 3, $a$ and 5). The result is that we have a general resemblance between the new and the old bases, but many points of detail in which the one differs from the other.

The sculpture of the archaic columns, so far as I can judge, is of the same period as the cornice (see Plate III. and Fig. 4, a). The forms are of course larger and more simply treated. But the workmanship is of the same delicate archaic kind. On the column the remains of colour are slighter than on the cornice, where in some parts they are quite brilliant in reds and blues. We have the same reds in parts of the columns, and in other fragments we have remains of blue; the marble also is of the same quality, finer than that of the later temple, or at all events made to look finer by most careful workmanship. This workmanship is conspicuous in the architectural mouldings and flutings as compared with the later temple. Though I had no hesitation in selecting these archaic fragments, I have been glad since then to find the selection confirmed by an observation of our invaluable mason Pinker to this effect, that there is no trace of the use of a claw tool in the archaic remains. It abounds in the later temple.

But we have still some fragments to deal with. For instance, there are some pieces of fluted columns, including a large piece of a shaft, and a small piece of a lowermost drum, with an inscribed torus moulding, indicating a dedication, whether by Croesos or not we cannot say. We know from Herodotus (I. 92), that Croesos bore the expense of most of the columns of the temple as it existed in the time of Herodotus. We are entitled to assume that the older, like the later temple, had only a limited number of sculptured columns; the rest being merely fluted, as shown in Fig. $4, b$. Some of the inscribed fragments clearly belong to fluted columns, and may have been the gift of other persons, though no name but that of Croesos has been recovered. It should be stated that the fragments which $I$ have put together as bearing

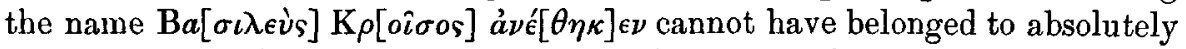
the same stone, since one has a top bed and another a bottom bed. Yet they must obviously have belonged to the same member in different columns.

We cannot well assume that the entire column had been sculptured from bottom to top, or eveu up the length of three drums, as Mr. Wood preferred for the later temple. It would be better to be content with only a lowermost sculptured drum on the analogy of Egyptian columns, as at Karnak and Medinet Abou, where we have only one row of figures, the rest of the column 


\section{EPHESUS}

\section{Archalc temple of Artemis}
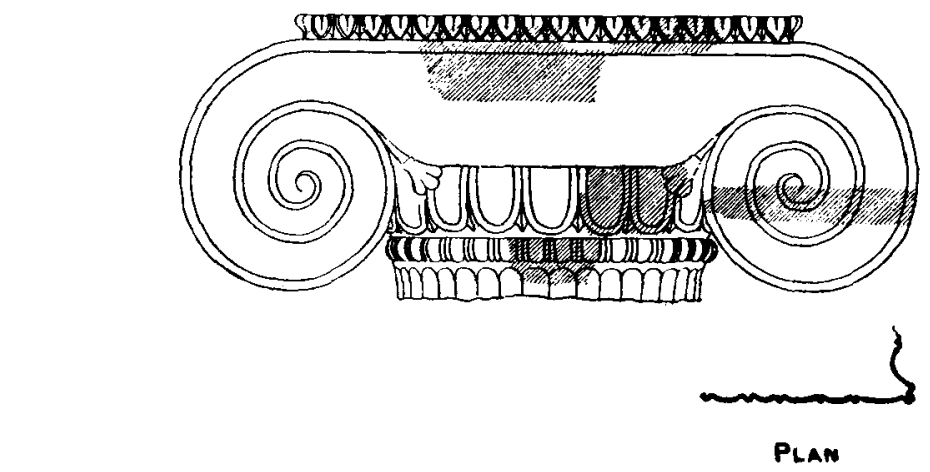

Hatching EHEW

Existinc Pontrome.
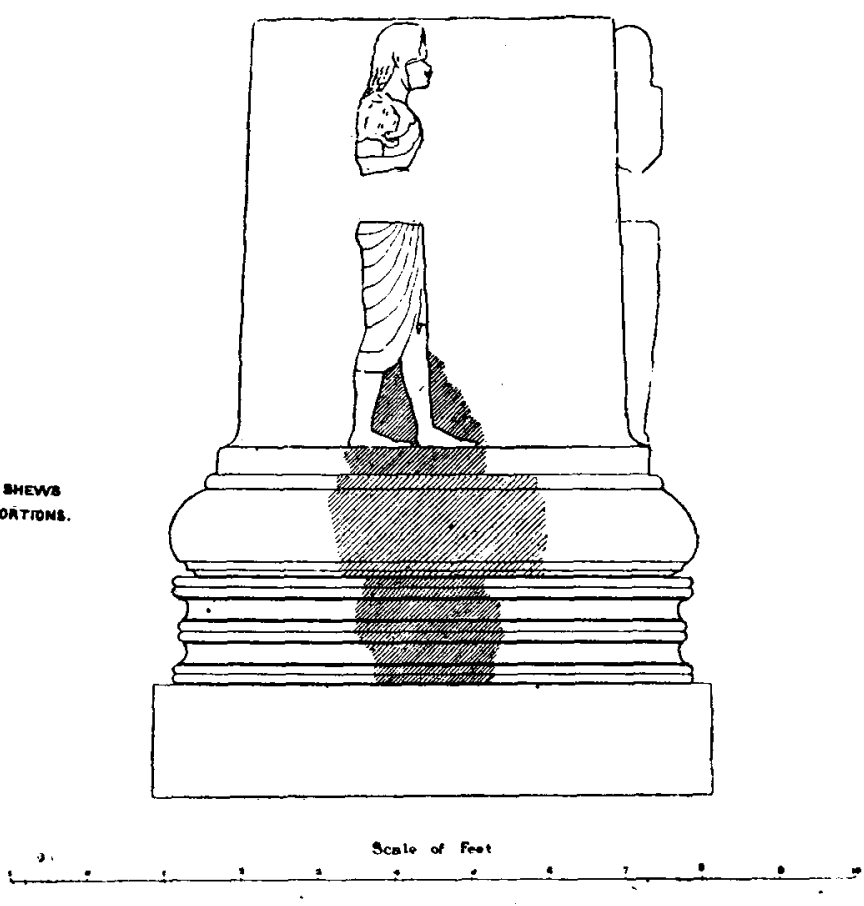

Fig. 5. 
being covered by mere patterns. If then the Ephesian columns were fluted all the way down to the lowermost drum, it is conceivable that the fluted fragment of which I have spoken may have come immediately above the sculptured drum. A strong objection however is, that the inscription is so placed on the torus as to be looked down on, not up to.

As I am not proposing to deal with the whole question of this archaic temple, only with such parts as appear to have been made out, it will be enough to mention further, that we possess a stone from the cella wall and several fragments which have enabled Mr. Elsey Smith to restore the capital and necking of a column (Fig. 5). On one of these fragments are remains of strong red colour. On another, a hollow line running round the volute has been filled in with lead, and gilded. On a third, the canal of the volute instead of being hollow is raised precisely as in the capital of the archaic temple at Samos.

The date of the archaic temple from which these fragments have so strangely survived, is I think determined by the inscribed mouldings bearing the name of Croesos, taken together with the statement of Herodotus, that most of the columns had been the gift of that king. Herodotus spoke of the temple which existed in his time, and he had good means of knowing the. truth from his residence close at hand in Samos. Croesos, we are told, had at one time laid siege to Ephesus, on which occasion the Ephesians had sought protection by connecting the temple of Artemis with the city walls by means of a rope. For some reason or other, whether before that incident or after it, a new temple certainly was built, largely by the aid of Croesos, The architect for a while was Chersiphron, of whom we hear in various ways. The sculptured columns must have been executed during his office. But nothing is said of the sculptors who had been employed. In connection with them I have only a passing conjecture to offer.

Comparing these archaic fragments from Ephesus with the marble statue of Nikè by Archermos, now in the Museum at Athens, I thought that the differences of style were of such a kind as would be expected from a son of Archermos. They are the differences of a new generation at a time of active progress in art. Archermos was followed and surpassed by his son Bupalos, whose works we are told were much admired centuries after his time in Rome, where many of them were to be seen. Greece was plundered for his works. Bupalos and the family of sculptors to which he belonged worked in marble. He was an architect, and sculptured reliefs in marble. We read of figures of the Graces by him in Smyrna and Pergamon. He had therefore been employed in the immediate neighbourhood of Ephesus. That he worked in Ephesus is not directly stated. We know this however, that the poet Hipponax was a native of Ephesus, that Bupalos made caricatures of the poet, that Hipponax revenged himself by a stinging satire in iambics- Acer hostis Bupalo,' as Horace says. There is of course no proof that this happened in Ephesus, the native town of Hipponax. It might have happened in Clazomenae, where Hipponax lived after he had been expelled from Ephesus on account of his poetic satires. But the style of the sculpture has strongly impressed me as just such as would be expected from a sculptor of the age 


\section{REMAINS OF ARCHAIC TEMPLE OF ARTEMIS AT EPHESUS.}

and traditions of Bupalos. About the contemporaneousness of Croesos, Hipponax, Bupalos, and these sculptured fragments, I see no reason to have the smallest doubt, and if that is so, we obtain a standard of date which will be useful in reference to other archaic sculptures, such as the Harpy tomb, the Branchidae statues, and in particular the metopes of the oldest temple at Selinus in Sicily.

A. S. Murray. 
J. H. S. VOL. X. (1889; PL III.

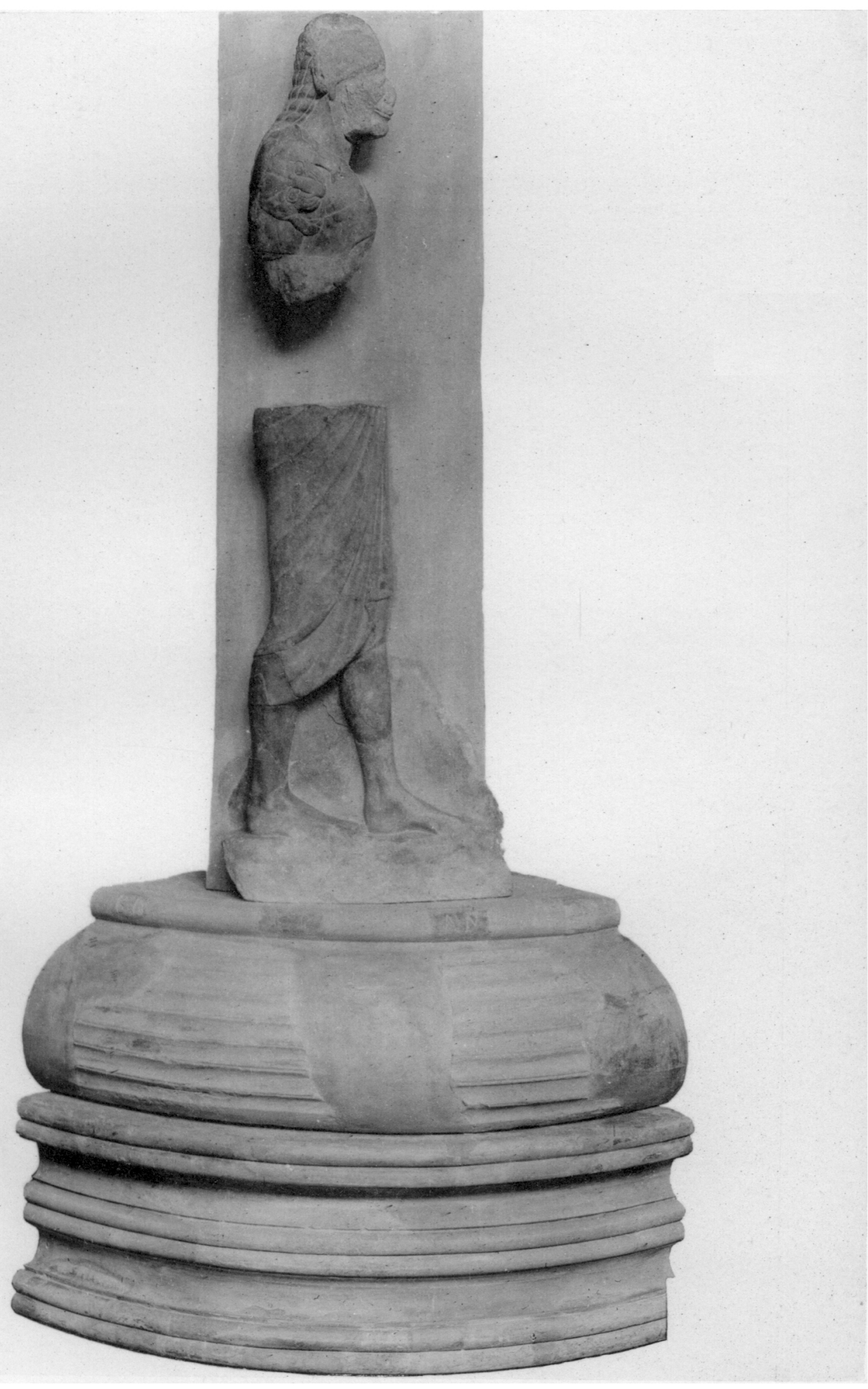

BASE OF COLUMN FROM THE ARCHAIC TEMPLE

OF ARTEMIS AT EPHESOS. 


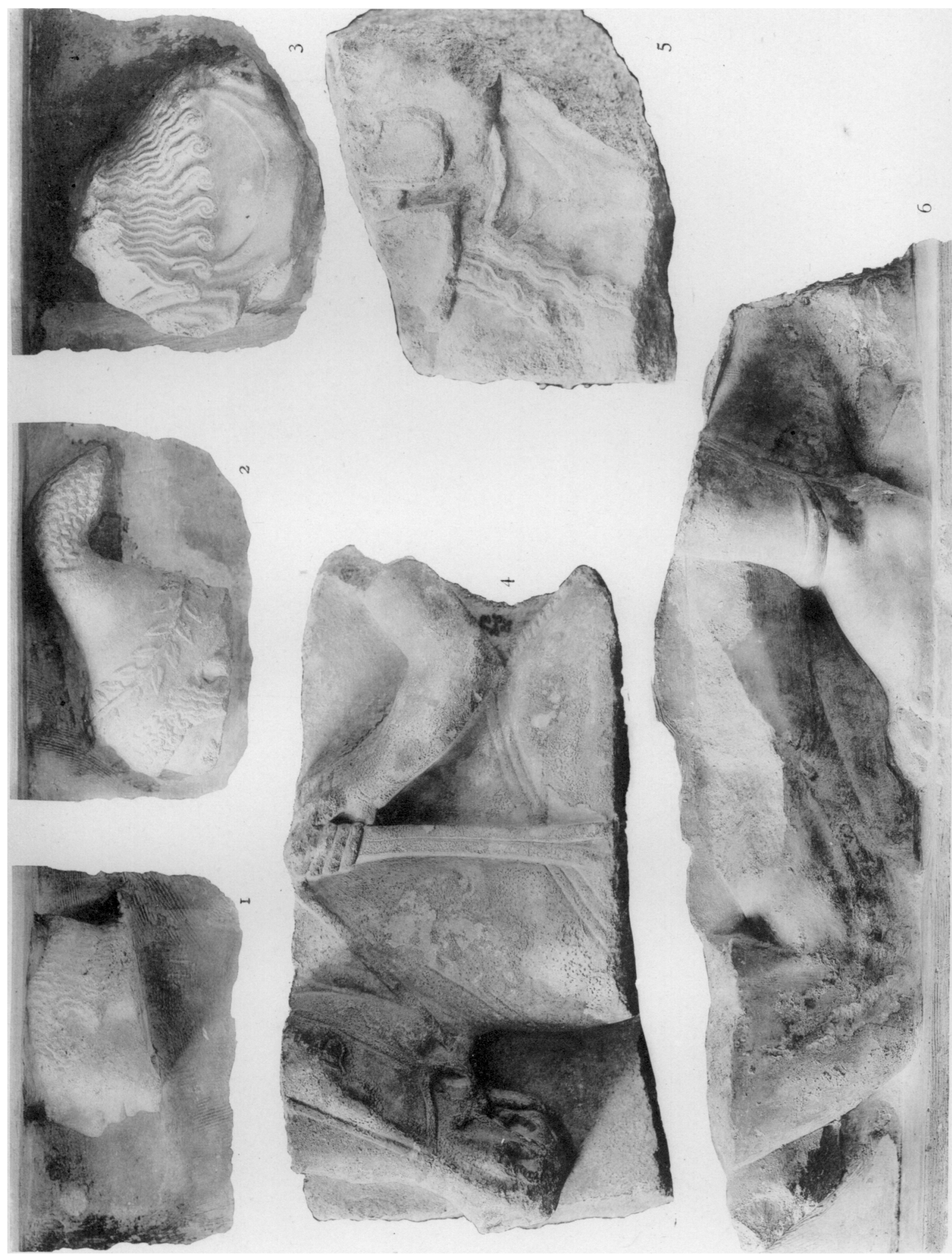

